УДК 378.014:303.424]:001.4(045)

DOI:

Ірина Щербак, кандидат педагогічних наук, викладач кафедри інформатики Комунального закладу “Харківська гуманітарно-педагогічна академія"

Харківської обласної ради

\title{
АНАЛІЗ СТРАТЕГІЙ ПОЗИЦІОНУВАННЯ ПРОВІДНИХ УНІВЕРСИТЕТІВ ВЕЛИКОБРИТАНІЇ В МІЖНАРОДНОМУ ІНФОРМАЦИЙНОМУ ПРОСТОРІ ЗА ГЛОБАЛЬНИМ ІНДИКАТОРОМ "КОМФОРТ"
}

Стаття присвячена висвітленню результатів аналізу стратегій позиціонування провідних європейських закладів вищої освіти щзодо комфорту навчання та проживання студентів. На підставі проведеного аналізу офіиійних сайтів університетів, повідомлень із засобів масової інформації, радіо, телебачення, з'ясовано основні форми та методи позиціонування закладів вищої освіти. Визначено не типові, креативні підходи щодо позиціонування провідних університетів Великобританії, що сприяє залученню до навчання максимальноі кількості абітурієнтів і утриманню стійких позицій на ринку освітніх послуг.

Ключові слова: Великобританія; стратегія позиціонування; комфорт; інфраструктура; провідний університет.

Jim. 9.

Iryna Shcherbak, Ph.D.(Pedagogy), Lecturer of the Informatics Department Municipal Establishment "Kharkiv Humanitarian-Pedagogical Academy” Kharkiv Regional Council

\section{ANALYSIS OF STRATEGIES FOR POSITIONING LEADING UK UNIVERSITIES IN THE INTERNATIONAL INFORMATION SPACE BEHIND THE GLOBAL INDICATOR "COMFORT"}

The article is devoted to highlighting the results of the analysis of positioning strategies of leading European higher education institutions regarding the comfort of learning and student living. Based on the analysis of the official websites of universities, reports from the media, radio, television, the main forms and methods of positioning of higher educational institutions have been clarified. Defined are not typical, creative approaches to the positioning of leading UK universities. For example, there is mentoring at the University of Manchester. The University of Oxford Language Center conducts preparatory courses for new international education applicants. Students of the University of Cambridge and Manchester shoot videos about the comfort of staying in these institutions, students and employees of the University of Edinburgh - about access to one of the largest academic libraries in the world, the opportunity to work in more than 30 computer laboratories, and receive interest-free loans for laptops; use childcare services, free services of the university medical center.

All universities use a university-specific focus method. The presence in Oxford of sports clubs, swimming pools, gyms, tennis courts, etc., a hostel. There is a student radio station in Cambridge, and several newspapers are published. On the territory of the University of Manchester there are many cafes, museums, clubs and communities of interest, sports clubs. The University of Bristol has dozens of campuses, a network of university libraries, gyms and tennis courts, as well as shops, bookstores and cozy cafes. The Universities of Oxford, Cambridge and Edinburgh have a support service for students with disabilities.

All these advantages allow attracting the maximum number of applicants to training and maintaining a stable position in the educational services market.

Keywords: Great Britain; positioning strategy; comfort; infrastructure; leading university.

$\Pi$ остановка проблеми в загальному вигляді. Сьогодні в європейській вищій освіті провідною $є$ тенденція до масифікації освітнього процесу та як наслідок цього - зниження якості освіти. Питання якості освіти постало в європейському освітньому просторі внаслідок швидкого кількісного зростання закладів вищої освіти, яке відбулось у середині ХХ ст. Відповідно до офіційних документів та теоретичних досліджень, прямими причинами виникнення тенденції до масифікації вищої освіти були зміни, що відбувались в Свропі, зокрема економічне зростання та соціокультурне піднесення, спричинене науково-технічною революцією розпочатою у ХІХ ст., а також процесами демократизації, прийняттям ідеології лібералізму та перемогою культури споживання населення. Тому в середині ХХ ст. 3'явилася ідея побудови суспільства, заснованого на знаннях, де вони (а отже, й освіта) є основою соціального й індивідуального розвитку [8].

Таким чином, $з$ метою підвищення якості 
АНАЛІЗ СТРАТЕГІЙ ПОЗИЦІОНУВАННЯ ПРОВІДНИХУНІВЕРСИТЕТІВ ВЕЛИКОБРИТАНІЇ В МІЖНАРОДНОМУ ІНФОРМАЦЙНОМУ ПРОСТОРІ ЗАГЛОБАЛЬНИМ ІНДИКАТОРОМ “КОМФОРТ"

освіти актуальним постає питання аналізу провідних університетів Свропи, зокрема їх стратегій позиціонування за глобальними індикаторами.

Аналіз досліджень і публікацій. Проблемам європейської освіти присвячені праці таких науковців: Й. Аль-Юсефа, К. Біницької, О. Біницької, С. Болсман, Г. Бучківської, П. Волкера, Д. Гіларда, В. Греськової, Дж. Девіса, П. Кіллінглі, Г. Келлера, C. Ломера, Дж. Пітмена, Р. Рудзкі. Питань стратегій позиціонування закладів вищої освіти, зокрема стратегічним перспективам вивчали Б. Братаніч, Т. Примак, П. Темпорал, А. Харківська та ін.

Формулювання цілей статті. Визначити основні форми та методи позиціонування провідних університетів. Проаналізуватистратегії позиціонування провідних університетів Великобританії за глобальним індикатором “комфорт" з його показниками, з'ясувати їх сильні та слабкі сторони.

Виклад основного матеріалу. Позиціонування - одне з ключових стратегічних рішень, прийнятих під час праці на ринку. Воно забезпечує несуперечність і узгодженість всіх операційних рішень і дій, що дає змогу сформувати однозначне сприйняття ринком пропозиції компанії. У сучасних умовах, коли заклади вищої освіти змушені працювати в ринкових умовах, вести конкурентну боротьбу за абітурієнтів, їм слід використовувати стратегії, що дають можливість бути більш конкурентоспроможними й ефективними [9].

У попередніх наукових розвідках нами було визначено поняття глобальних індикаторів, за якими аналізують стратегії позиціонування закладів вищої освіти (ЗВО). Наразі зробимо аналіз стратегій позиціонування, за глобальним індикатором “комфорт”, на прикладі провідних університетів Великобританії.

Тож проаналізуємо стратегію позиціонування Оксфордського університету за глобальним індикатором “комфорт”, що включає соціальну та навчальну інфраструктури.

Сайти університету широко рекламують діяльність конфіденційної служби консультування студентів, яка проводить семінари і навіть індивідуальну терапію. Наявні підкасти з різних тем - від уважності до перфекціонізму та підготовки до іспитів. Ще одним суттєвим кроком стратегії позиціонування ЗВО є розповсюдження інформації серед абітурієнтів щодо Дня відкритих дверей, участі у програмі “6/12/24 години в Оксфорді”, особистого або віртуального відвідування університету.

Оксфорд позиціонує спрямованість своєї стратегії на людей із обмеженими можливостями, адже в закладі розроблена програма підтримки інвалідності та в свої стінах він навчає понад 3500 студентів із обмеженими можливостями, про що теж інформує офіційна сторінка сайту університету.

Також PR-менеджерами створений сайт, що позиціонує інші послуги 3ВО, в якому наголошується: “Будь ласка, зверніться до розділу ресурсів університетського веб-сайту, щоб дізнатися про всі послуги для студентів" [5].

Усі сайти в Інтернетмережі, що пов'язані з Оксфордом, передовсім позиціонують комфорт цього закладу вищої освіти для життя та навчання студентів, викладачів і науковців. "University of Oxford - це маленька держава, до складу якої входить 38 коледжів і 6 закритих коледжів (Permanent Private Hall), заснованих протестантськими і католицькими організаціями. У коледжах Оксфордського університету немає поділу на спеціалізації, тому студент будь-якого коледжу може вчитися на кожному з факультетів. Oxford Colleges “ це унікальні академічні спільноти, які формують неповторний вигляд університету” [2].

Аналіз стратегії позиціонування за глобальним індикатором “комфорт" показав, що кожен 3 Оксфордських коледжів має обідні зали, бари, бібліотеки, кімнати відпочинку та гуртожитки. На території університету є театр Sheldonian, музеї, а також власне видавництво, що публікує знамениті Оксфордські словники, дендрарій і найстаріший в Англії ботанічний сад.

Та хоча університет і має великі території, всіх своїх студентів забезпечити гуртожитком він не може (лише $57 \%$ студентів і $70 \%$ першокурсників забезпечуються житлом), через це PR-менеджери рекламують те, що більшість коледжів університету розташовані в центрі міста або недалеко від нього, і до університету студентам можна дістатися на велосипеді або безкоштовним університетським транспортом.

Важливим для позиціонування комфорту університету є діяльність студентських спілок (SU), інформація про які надається у волонтерських та студентських засобах масової інформації. Цікавим для нас $є$ те що SU інформують про наявність вільних аудиторій, у яких можна проводити заняття, “круглі столи” та інші засідання. Також ці спілки надають низку інших послуг, таких як: безкоштовне консультування та обслуговування, ремонт велосипедів тощо. Цю інформацію можна знайти на сайтах, блогах та інформаційних стендах.

Наступним розглянемо та зробимо аналіз стратегій позиціонування Кембриджського університету за цим же індикатором. 


\section{АНАЛІЗ СТРАТЕГІЙ ПОЗИЦІОНУВАННЯ ПРОВІДНИХУНІВЕРСИТЕТІВ ВЕЛИКОБРИТАНІЇ В МІЖНАРОДНОМУ ІНФОРМАЦЙННОМУ ПРОСТОРІ ЗА ГЛОБАЛЬНИМ ІНДИКАТОРОМ “КОМФОРТ”}

Суттєвим кроком для сприяння стратегій позиціонування щодо комфорту університету є розповсюдження реклами серед підписників Кембриджського університету стосовно його соціальної та навчальної інфраструктури університету. У цих повідомлення наголошувалось, що Кембриджський університет $є$ дослідницьким центром із багатьма лабораторіями та навчальними аудиторіями; має найбільшу у світі бібліотеку, яка об'єднує 114 близько звичайних і одну центральну університетську бібліотеку та налічує 8 млн різних творів; Ботанічний сад; Музей археології та антропології; Зоологічний музей; Художній музей Фіцуільяма; Інститут полярних досліджень ім. Р. Скотта й інших визначних пам'яток. Кембридж пишається своїм собором Королівського коледжу, який будували майже 100 років.

Також університет приділяє велику увагу спорту - він має чимало фітнес-залів, тренажерних залів, залів для занять важкою атлетикою, стадіони для футболу, бейсболу, регбі, а також майданчики для гольфу, тенісного корту, баскетболу тощо.

Новини 3 життя Кембриджського університету постійно висвітлюються у власних газетах, на радіо. У закладі функціонують комедійний гурток Footlights, театральна спілка, студентська рада, яка бере активну участь у розв'язанні проблем здобувачів освіти [6].

Студенти університету беруть активну участь у позиціонуванні стратегій ЗВО. Вони створили та розповсюдили по мережі Інтернет відеоролик про соціальну та навчальну інфраструктури очима студентів. У цьому їм допомагали виконавчий асистент Лорен Башам та заступник директора 3 комунікацій Джеймс Харді. “Оскільки будівлі Кембриджського університету розкидані хаотично по всьому місту, їм нерідко доводиться сусідити з магазинами, ресторанами, кафе, галасливими й атмосферними пабами, чому невимовно раді студенти, оскільки їм не потрібно виходити далеко за межі свого гуртожитку, щоб пропустити кухлик пива з друзями або закупити продукти на тиждень" [6].

Одним із переваг Кембриджського університету $\epsilon$ те, що заклад задовольняє потребу всіх здобувачів освіти у проживанні та надає гуртожиток на весь час навчання.

Проаналізувавши стратегії позиціонування Кембриджського університету, можна сказати, що соціальна та навчальна інфраструктура 3ВО перебуває на високому рівні.

У стратегічному плані Единбурзького університету, розміщеному на офіційному сайті, наголошується: “Ми прагнемо, щоб всі студенти i співробітники вчилися в гостинному i підтримуючому середовищі з високоякісними зручностями і почуттям спільності" [4].

Загалом стратегія позиціонування Единбурзького університету має типову для вищепроаналізованих університетів спрямованість.

У відеороликах створених про діяльність закладу вищої освіти розповсюджується інформація щодо можливості користування однією 3 найбільших академічних бібліотек, яка має близько 1,8 млн друкованих томів; можливість відвідувати понад 60 спортивних клубів; працювати у комп'ютерних лабораторіях із відкритим цілодобовим доступом; студентам 3 обмеженими можливостями користуватися службою підтримки; безкоштовними послугами університетського медичного центру. Незвичним для нас є надання безвідсоткових кредитів на ноутбуки та послуг по догляду за дітьми, для батьків, що поєднують батьківські обов'язки і навчання.

На сайті Единбурзького університету популяризується діяльність понад 280 товариств Асоціацій студентів під гаслом: “Приєднуйтесь до активного студентського співтовариства в одному 3 найпривабливіших місць у світі для життя. Відкрийте для себе життя в Единбурзі” [1].

Единбургом широко рекламується наявність кількох музеїв: музей музичних інструментів, у якому налічується понад 1000 експонатів, багато 3 яких досі функціонують; Музей геології Кокберн і Музей природної історії, у яких викладачі наочно демонструють здобувачам освіти ексклюзивні експонати. Галерея Талбота Райса, у якій відбуваються виставки сучасного мистецтва, даючи молодим художникам можливість показувати свої роботи. Всі ці пам'ятки привертають увагу не тільки студентів, а й туристів з різних країн, що, беззаперечно, є гарним підгрунтям впізнаваності бренду закладу вищої освіти.

Наступним проаналізуємо стратегії позиціонування Манчестерського університету за глобальним індикатором “комфорт”. Нехарактерною ознакою стратегії позиціонування цього ЗВО є спрямованість на соціальність та відповідальність, тобто усі бажаючі мають доступ до схем наставництва. Однією з таких схем $\epsilon$ "Manchester Gold" [3] - програма, в якій студент в парі з одним ексклюзивним наставником впродовж шести місяців отримує необхідну інформацію, поради та рекомендації.

Під час проведення Днів відкритих дверей у Манчестерському університеті демонструються 


\section{АНАЛІЗСТРАТЕГІЙ ПОЗИЦОНУВАННЯ ПРОВІДНИХ УНІВЕРСИТЕТІВ ВЕЛИКОБРИТАНІЇ В МГЖНАРОДНОМУ ІНФОРМАЦЙНОМУ ПРОСТОРІЗА ГЛОБАЛЬНИМ ІНДИКАТОРОМ “КОМФОРТ”}

відеоролики про кампус 3ВО, який налічує 229 будівель, що розташовані на 270 гектарах. Університет розташований у центрі Манчестера, що дає можливість легко дістатися до будь-якого куточка міста. Одним 3 привабливих моментів для студентів є безкоштовне відвідування кафе, крамниць, культурних установ, музеїв, розміщених поруч із закладом. Манчестер має велику кількість храмів та будівель 3 величною архітектурою, красиві парки та сквери, що теж приваблює майбутніх здобувачів вищої освіти.

Широко рекламуються у міжнародному інформаційному просторі відомості щодо діяльності співтовариств та спортивних клубів університету, яких налічується близько чотирьох десятків. Також в університеті працює музей, де розміщено понад 4 млн різних експонатів; Галерея мистецтв Вітворта, де, крім постійної експозиції, організовуються тимчасові виставки відомих авторів; студентський театр "Контакт", що має будівлю у вигляді фортеці, реклама якого подається навіть на транспортних засобах міста.

На останок розглянемо стратегію позиціонування комфорту Брістольського університету.

В ефірі університетського веб-радіо постійно популяризується стратегія позиціонування комфортності навчання та проживання у Брістольському університеті. Випуски радіоефірів за допомогою мережі Інтернет можна слухати в різних куточках світу. В ефірі одного з радіо випусків була надана інформація про те, що “Брістольський університет розташований у північній частині Бристоля, недалеко від річки Ейвон. Подорож до Лондона займає дві години. Інфраструктура складається 3 десятка будинків, зведених у різні часи і різними архітекторами. Брістольський університет змішує в собі будівлі в стилі Оксфорда (наприклад, кампус Уиллс-хол), неоготичні вежі (наприклад, Уиллс Меморіал Білдінг, де розташована правова школа) і споруди, побудовані в стилі класицизму (наприклад, музична школа в Вікторіас Румс). Також у володінні Брістольського університету знаходяться кращі зразки георгіанської архітектури - Кліфтон Хілл, де розташовуються студентські кампуси, Роял-Форт, що став домівкою для кількох дослідницьких центрів, і Голдні-хол, ще один студентський будинок. У розпорядженні студентів -десятки кампусів, мережа університетських бібліотек, спортивні зали і тенісні корти, а також магазини, книжкові крамниці і затишні кафе” [7].

Висновки. Отже, проаналізувавши п'ять провідних університетів Великобританії за глобальним індикатором “комфорт”, який охоплює соціальну та навчальну інфраструктури, можемо відзначити, що до найпоширеніших форм позиціонування університетів слід віднести такі: індивідуальні бесіди, дистанційні або онлайн консультації, на яких можуть поставити будь-які особисті запитання. Наприклад, в Манчестерському університеті існує наставництво, де до студента прикріплюється наставник протягом 6-місячного періоду, який надає необхідну інформацію, поради та рекомендації щодо навчання в університеті. Створення курсів, мовний центр Оксфордського університету проводить підготовчі курси для нових іноземних студентів. Шеститижнева інтенсивна програма призначена для забезпечення необхідних академічних мов і навичок грамотності для досягнення успіху в англомовному університетському середовищі.

Усі університети використовують метод демонстрування на офіційному веб-сайті, у ЗМІ та у власних соціальних мережах. Наприклад, студенти Кембриджського, Манчестерських університетів знімають відеоролики про комфортність перебування у зазначених закладах вищої освіти, студенти та працівники Единбурзького університету - про доступ до однієї 3 найбільших академічних бібліотек у світі, можливість працювати в понад 30 комп'ютерних лабораторіях із відкритим цілодобовим доступом, отримувати безвідсоткові кредити на ноутбуки; користуватися послугами по догляду за дітьми, полегшуючи поєднання батьківських обов'язків і навчання, безкоштовнимипослугамиуніверситетського медичного центру.

Усі університети використовують метод концентрації на особливостях університету. Оксфордський університет має 83 спортивні клуби, басейн, тренажерний зал, спортивний зал, бігові доріжки, майданчики для гри у теніс тощо, гуртожиток. На території Кембриджського університету функціонують кілька спортивних комплексів, стадіони для гри в футбол, бейсбол, регбі, майданчики для гри в баскетбол і гольф, тенісний корт тощо, театральне співтовариство, студентська рада, комедійний гурток “Footlights", гуртожиток на весь час навчання. У Кембриджі працює студентська радіостанція, випускається кілька газет, в яких містяться найостанніші новини про життя рідного ЗВО і дослідження, які проводяться у ньому. На території Манчестерського університету є безліч кафе, музеїв, клубів і співтовариств за інтересами, спортивних клубів. У Брістольському університеті є десятки кампусів, мережа університетських бібліотек, спортивні зали і тенісні корти, а також магазини, книжкові крамниці і затишні кафе. Оксфордський, 


\section{АНАЛІЗ СТРАТЕГІЙПОЗИЦІОНУВАННЯ ПРОВІДНИХУНІВЕРСИТЕТІВ ВЕЛИКОБРИТАНІЇ В МІЖНАРОДНОМУ ІНФОРМАЦЙНОМУ ПРОСТОРІ ЗА ГЛОБАЛЬНИМ ІНДИКАТОРОМ “КОМФОРТ”}

Кембриджський університети проводять змагання 3 веслування між собою. В Оксфордському, Кембриджському та Единбурзькому університетах працює служба підтримки для студентів із обмеженими можливостями. В Единбурзькому університеті створено Асоціацію студентів університету, яка налічує понад 280 товариств.

Проведене нами дослідження показало, що всі провідні університети Великобританії приділяють максимальну увагу стратегії позиціонування щодо комфорту, адже це є важливою складовою для залучення здобувачів вищої освіти і підтримання своєї конкурентоспроможності. Сподіваємось, що досвід Свропейських країн стане в нагоді для вітчизняних закладів вищої освіти, з метою просування їх у міжнародний інформаційний простір.

\section{ЛІТЕРАТУРА}

1. Clubs and societies. URL: https://www.ed.ac.uk/ studying/undergraduate__дата звернення 07.12.2019).

2. Faculties and colleges of the University of Oxford. URL: https:/www.unipage.net/en/university of oxford (дата звернення: 07.12.2019).

3. ManchesterGold.URL:https://www.manchester.ac.uk/ research/researcher-development (дата звернення: 09.12.2019).

4. Strategic plan 2016. URL: https://www.ed.ac.uk/ governance-strategic-planning/strategic-planning/ strategic-plan/what-makes-us-edinburgh/our-people (дата звернення: 09.12.2019).

5. Undergraduate admissions and outreach.URL: https://www.ox.ac.uk (дата звернення: 07.12.2019).

6. University of Cambridge. URL: https:// www.unipage.net/en/university_of_cambridge (дата звернення: 17.05.2019).

7. UWE Bristol. WEbradio. URL: https:// Soundcloud.Com/Uwebristol (дата звернення: 09.12.2019).

8. Біницька К., Бучківська Г., Біницька О., Греськова В. Європейська система забезпечення якості вищої освіти: досвід республіки Польща. Молодь і ринок. №2 (181). 2020. С. 47-54. DOI: https://doi.org/10.24919/23084634.2020.208425.
9. Харківська А. А. Стратегія позиціонування закладу вищої освіти: від управління витратами до управління результатами. Актуальні питання гуманітарних наук. Том 2. № 22. 2018. С. 133137. DOI: https://doi.org/10.24919/2308-4863.2/ 22.166984 .

\section{REFERENCES}

1. Undergraduate admissions and outreach. Available at: https://www.ox.ac.uk (accessed 07 Dec. 2019). [in English].

2. Faculties and colleges of the University of Oxford. Available at: https://www.unipage.net/en/university of oxford (accessed 07 Dec. 2019). [in English].

3. University of Cambridge. Available at: https:// www.unipage.net/en/university_of_cambridge (accessed 17 May 2019). [in English].

4. Strategic plan 2016. Available at: https:// www.ed.ac.uk/governance-strategic-planning/ strategic-planning/strategic-plan/what-makes-usedinburgh/our-people (accessed 09 Dec. 2019). [in Englisn].

5. Clubs and societies. Available at: https:// www.ed.ac.uk/studying/undergraduate (accessed 07 Dec. 2019). [in Englisn].

6. Manchester Gold. Available at: https:// www.manchester.ac.uk/research/researcherdevelopment (accessed 09 Dec. 2019). [in Englisn].

7. UWE Bristol. WEbradio. Available at: https:// Soundcloud.Com/Uwebristol (accessed: 09 Dec. 2019). [in Englisn].

8. Binytska, K., Buchkivska, H., Binytska, O. \& Hreskova, V. (2020). Yevropeiska systema zabezpechennia yakosti vyshchoi osvity: dosvid respubliky Polshcha [European Quality Assurance System for Higher Education: Experience of the Republic of Poland]. Youth \& market. No.2 (181). pp. 47-54. DOI: https://doi.org/10.24919/23084634.2020.208425. [in Ukrainian].

9. Kharkivska, A. A. (2018). Stratehiia pozytsionuvannia zakladu vyshchoi osvity: vid upravlinnia vytratamy do upravlinnia rezultatamy [Higher education positioning strategy: from cost management to results management]. Vol. 2. No. 22. pp. 133-137. DOI: https://doi.org/10.24919/23084863.2/22.166984. [in Ukrainian].

Стаття надійшла до редакції 20.08.2020

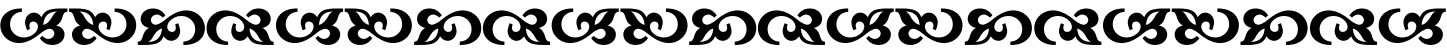

"Була б мета поставлена - а ланщюжок проб і помилок сам приведе до бажаного результату".

Харукі Мурақамі

японський письменник і перекладач

\section{G5808nc2058080}

